\title{
ANALISIS KESALAHAN JAWABAN SISWA PADA KEMAMPUAN PEMAHAMAN MATEMATIS MELALUI PEMBELAJARAN KONTEKSTUAL
}

\author{
Nia Jusniani \\ Universitas Suryakancana \\ niajusniani2010@gmail.com
}

\section{Penerimaan : 30 Mei 2018}

Diterima: 30 Juni 2018

\begin{abstract}
ABSTRAK
Pembelajaran matematika yang selama ini memang dianggap sulit oleh sebagian besar siswa. Hasil kontes PISA beberapa tahun ini skor siswa Indonesia masih rendah. Penelitian ini bertujuan untuk menganalisis kesalahan jawaban siswa pada kemampuan pemahaman matematis siswa, untuk mengetahui kesulitan siswa dalam menjawab soal matematika melalui pembelajaran matematika menggunakan pembelajaran kontekstual. Model pembelajaran pendekatan kontekstual ini menuntut siswa untuk lebih aktif dalam mencari sendiri permasalahan yang berikan guru dari serangkaian materi atau masalah yang berbentuk kontekstual. Sehingga dapat memotivasi siswa supaya dalam menyelesaikan suatu masalah dalam matematika. Materi yang diberikan dalam pelaksanaan penelitian yaitu materi lingkaran pada semester genap kelas VII SMP. Metode penelitian ini adalah metode kualitatif dengan menggunakan grounded theory. Instrumen yang digunakan yaitu instrumen tes (instrumen tes dan observasi). Lembar jawaban siswa untuk dianalisis jenis kesalahan yang dilakukan siswa yang sesuai dengan indikator kemampuan pemahaman matematis. Penelitian ini terdiri dari satu kelas yang dilaksanakan dalam delapan pertemuan diberikan perlakuan berupa pembelajaran kontekstual. Berdasarkan hasil kesalahan yang banyak ditemukan pada indikator menyajikan situasi matematika kedalam berbagai cara serta mengetahui perbedaannya, dan mengembangkan konsep yang telah dipelajari. Jenis kesalahan yang telah dilakukan siswa dalam menjawab soal pemahaman matematis siswa sebagian besar pada kesalahan biasa dan miskonsepsi. Hasil analisis lembar observasi menunjukkan bahwa selama pembelajaran berlangsung aktivitas siswa. Dengan demikian pembelajaran kontekstual dapat mengurangi kesalahan siswa dalam menjawab soal kemampuan pemahaman matematis. Hasil analisis kesalahan jawaban siswa, diperolah bahwa siswa masih banyak kesalahan dalam indikator mengidentifikasi sifat-sifat konsep dan mengenal syarat yang menentukan suatu konsep sebanyak 53,05\%.
\end{abstract}

Kata Kunci: kemampuan pemahaman matematis, analsis kesalahan jawaban, kontekstual.

\section{PENDAHULUAN}

NCTM (2000) menetapkan lima kemampuan matematis, meliputi: penalaran matematis, representasi matematis, koneksi matematis, komunikasi matematis, dan pemecahan masalah matematis. Berdasarkan hasil PISA (Programme for International Student Assessment) yang merupakan studi tentang program penilaian siswa tingkat internasional yang 
diselenggarakan oleh Organization for Economic Cooperation and Development (OECD) atau organisasi untuk kerjasama ekonomi dan pembangunan tahun 2009 bahwa kemampuan matematika siswa Indonesia, masih rendah. Proporsi siswa Indonesia yang memiliki kemampuan literasi matematika rendah (di bawah level 2) mencapai 76,6\%. Definisi rendah di sini menurut OECD adalah di bawah standar minimum literasi seseorang untuk berfungsi efektif dalam kehidupan abad 21. Ini berarti bahwa hampir $80 \%$ siswa tidak akan siap berfungsi efektif dalam kehidupan modern ini. kemampuan

Tujuan pembelajaran matematika di sekolah adalah supaya siswa memiliki kemampuan dalam memecahkan permasalahan sehari-hari. Hal ini sejalan dengan pendapat Bardu dan Beal (2010) bahwa dalam melakukan operasi matematika diperlukan suatu kemampuan dalam menyelesaikannya. Untuk dapat menyelesaikan masalah matematika, siswa harus memiliki kemampuan literasi matematika atau kemampuan membaca dan menulis yang berhubungan dengan matematika dalam kehidupan sehari-hari. Salah satu pembelajaran yang sesuai diantaranya pembelajaran kontekstual memiliki filosofi kontruktivisme, yakni belajar bukan hanya sekedar menghafal, melainkan mengkontruksi pengetahuan di dalam diri peserta didik itu sendiri.

Kegiatan analisis kesalahan siswa dalam menyelesaikan masalah matematika perlu dilakukan agar kesalahan-kesalahan yang dilakukan siswa dapat diketahui dan dapat ditindaklanjuti untuk memaksimalkan kemampuan belajar siswa. Dalam proses pembelajaran, guru harus mampu memahami kesalahan yang dialami siswa beserta penyebab-penyebab kesalahan tersebut muncul. Jika diketahui sumber masalahnya, guru dapat mencari solusi penyelesaian masalah tersebut. Terlebih dahulu guru harus mengetahui jenis-jenis kesalahan siswa dalam menjawab soal matematika, kemudian dapat diketahui penyebab dari kesalahan tersebut sehinnga dapat ditindaklanjuti dengan mencari solusi mengatasi sumber masalah kesalahan siswa tersebut.

Berdasarkan observasi, beberapa permasalahan dalam pembelajaran matematika yang dilakukan guru cenderung dengan pembelajaran konvensional. Ciri-ciri pembelajaran konvensional atau tradisional (Marpaung, 2010) sebagai berikut: (a) guru aktif mentransfer pengetahuan ke siswa (guru mengajari siswa); (b) siswa menerima pengetahuan secara pasif (siswa berusaha menghafalkan pengetahuan yang diterima); (c) pembelajaran dimulai oleh guru dengan menjelaskan konsep atau prosedur menyelesaikan soal, memberi soal-soal latihan 
pada siswa; (d) memeriksa dan memberi skor pada pekerjaan siswa; dan (e) memberi penjelasan lagi atau memberi tugas pekerjaan rumah pada siswa.

Pembelajaran matematika dengan pendekatan kontekstual, siswa diberi permasalahan, kemudian mereka membuat hubungan dengan matematika, dan siswa tidak langsung menggunakan algoritma untuk menyelesaikan masalah tetapi menggunakan konsep matematika yang mereka pahami. Siswa diberi kesempatan untuk berpikir, karena setiap siswa mempunyai hak untuk berpikir. Matematika tidak hanya berisi prosedur dan algoritma yang harus dipelajari siswa, tetapi suatu pembelajaran yang dapat dipelajari melalui pengalaman. Oleh karena itu, pembelajaran matematika hendaknya menggambarkan aktivitas kehidupan dan penggunaan benda manipulatif merupakan salah satu untuk mewujudkannya.

\section{Pendekatan Kontekstual}

Menurut Cahyo (2013:), Pembelajaran kontekstual (contextual teaching and learning) merupakan suatu proses pendidikan yang holistik dan bertujuan memotivasi siswa untuk memahami makna materi pelajaran yang dipelajarinya dengan mengaitkan materi tersebut dengan konteks kehidupan mereka sehari-hari (konteks pribadi, sosial, dan kultural). Menurut Johnson (Suyadi, 2013:81) strategi pembelajaran contextual teaching and learning (CTL) merupakan strategi pembelajaran yang menekankan pada proses keterlibatan peserta didik secara penuh untuk dapat menemukan hubungan antara materi yang dipelajari dengan realitas kehidupan nyata, sehingga mendorong peserta didik untuk menerapkannya dalam kehidupan sehari-hari. Dapat disimpulkan, pendekatan kontekstual (contextual teaching and learning) adalah konsep pembelajaran yang menekankan keterlibatan seluruh peserta didik untuk memahami isi materi yang diberikan guru dengan mengaitkan materi pembelajaran kedalam konteks kehidupan nyata yang dialami peserta didik agar peserta didik dapat dengan mudah memahami isi materi yang diberikan guru, kemudian akan terwujudnya berbagai macam pemikiran dan berbagai pemahaman terhadap peserta didik. Sedangkan menurut Komalasari mengidentifikasi karakteristik pembelajaran kontekstual meliputi pembelajaran yang menerapkan konsep keterkaitan (relating), konsep pengalaman langsung (experince), konsep aplikasi (applying), konsep kerja sama (cooperating), konsep pengaturan diri (self-regulating), dan konsep penilaian (authentic assesment).

\section{Analisis Kesalahan Jawaban Siswa}


Menurut kamus besar Bahasa Indonesia (1996:37) analisis adalah penyelidikan terhadap suatu peristiwa dan untuk mengetahui keadaan yang sebenar-benarnya. Analisis mempunyai tujuan untuk mengetahui keadaan yang sebenarnya dari suatu pokok berbagai bagian dan penelaahannya bagian itu sendiri serta hubungan antar bagian. Malau (1996: 44) penyebab kesalahan yang sering dilakukan siswa dalam menyelesaikan soal-soal matematika dapat dilihat dari beberapa hal antara lain disebabkan kurangnya pemahaman atas materi prasyarat maupun materi pokok yang dipelajari, kurangnya penguasaan bahasa matematika, keliru menafsirkan atau menerapkan rumus, salah perhitungan, kurang teliti, lupa konsep. Hiebert dan Lefvre (dalam Mahmuda, 2011: 13) bahwa:" Conceptual knowledge is characterize most clearly as knowledge that rich in relationship. It can be thought of as connected web of knowledge, a network in which the linking relationships are as prominent as the discrete pieces of information". Menurut pendapat di atas, bahwa pengetahuan konseptual adalah suatu pengetahuan yang kaya akan hubungan-hubungan. Hubungan ini meliputi fakta dan sifat-sifat sehingga semua potongan informasi terkait pada suatu jaringan. Sejalan dengan itu, Suherman dkk.,(2001: 5) bahwa konsep-konsep matematika tersususn secara hierarkis, terstruktur, logis dan sistematis mulai dari konsep yang paling sederhana sampai pada konsep yang palingn kompleks. Hal ini artinya bahwa di dalam matematika terdapat konsep prasyarat dimana konsep ini sebagai dasar untuk memahami suatu topik atau konsep selanjutnya. Kesalahan konsep adalah kesalahan yang dilakukan siswa dalam menafsirkan istilah, konsep, dan prinsip.

Kegiatan analisis kesalahan siswa dalam menyelesaikan masalah matematika perlu dilakukan agar kesalahan-kesalahan yang dilakukan siswa dapat diketahui dan dapat ditindaklanjuti untuk memaksimalkan kemampuan belajar siswa. Dalam proses pembelajaran, guru harus mampu memahami kesalahan yang dialami siswa beserta penyebab-penyebab kesalahan tersebut muncul. Jika diketahui sumber masalahnya, guru dapat mengupayakan penyelesaian masalah tersebut. Terlebih dahulu guru harus mengetahui jenis-jenis kesalahan siswa dala menjawab soal matematika, kemudian dapat diketahui penyebab dari kesalahan tersebut sehinnga dapat ditindaklanjuti dengan mencari solusi mengatasi sumber masalah kesalahan siswa tersebut. 


\section{METODOLOGI PENELITIAN}

Penelitian Grounded Theory adalah metode penelitian kualitatif yang menggunakan sejumlah prosedur sistematis yang diarahkan untuk mengembangkan teori berorientasi tindakan, interaksi, atau proses dengan berlandaskan data yang diperoleh dari lapangan. Tujuan penelitian ini adalah mengkaji tentang kesalahan jawaban siswa dalam menjawab soal pemahaman matematika setelah penerapan pembelajaran matematika dengan Pendekatan kontekstual. Langkah-langkah penelitian grounded theory menurut Straus (1998) terdiri dari tiga langkah secara berurutan yaitu: open coding, selective coding, dan theoretical coding. Berikut ini tahapan kriteria dalam penelitian Grounded Theory:

1. Cocok (fit), teori yang dihasikan cocok dengan kenyataan sehari-hari sesuai bidang yang diteliti.

2. Dipahami (understanding), teori yang dihasilkan menggambarkan realitas (kenyataan) dan bersifat komprehensif, sehingga dapat dipahami oleh individu-individu yang diteliti maupun oleh peneliti.

3. Berlaku umum (generality), teori yang dihasilkan meliputi berbagai bidang yang bervariasi sehingga dapat diterapkan pada fenomena dalam konteks yang bermacammacam.

Pengawasan (control), teori yang dihasilkan mengandung hipotesis-hipotesis yang dapat digunakan dalam kegiatan membimbing secara sistematik untuk mengambil data aktual yang hanya berhubungan dengan fenomena terkait.

Populasi pada penelitian yang akan dilakukan ini adalah seluruh siswa dari SMP di Kabupaten Cianjur dengan katagori yang sama. Pertimbangan pemilihan siswa SMP sebagai subyek penelitian didasarkan pada (1) tingkat perkembangan kogitif siswa SMP yang masih pada tahap peralihan dari operasi konkrit ke operasi formal sehingga sesuai dengan penerapan pembelajaran kontekstual, (2) siswa kelas VII merupakan siswa baru yang berada pada masa transisi dari SD ke SMP sehingga lebih mudah diarahkan, terdapat sejumlah materi yang diperkirakan sesuai diterapkannya pembelajaran dengan menggunakan pendekatan kontekstual. 


\section{HASIL DAN PEMBAHASAN}

Langkah-langkah penelitian grounded theory menurut Straus (1998) terdiri dari tiga langkah secara berurutan yaitu: open coding, selective coding, dan theoretical coding. Langkah-langkah tersebut sebagai berikut:

\section{a. Tahap Open Coding}

Peneliti melakukan pengumpulan data awal dari hasil jawaban siswa tes akhir atau postes kemampuan pemahaman matematis, kemudian menganalisis lembar jawaban siswa pada tes akhir, dan komentar siswa pada wawancara. Setiap lembar jawaban siswa dianalisis untuk mendapatkan kategori kesalahan siswa dalam menjawab soal kemampuan pemahaman matematis. Data tersebut dibentuk ke dalam kategori-kategori awal tentang kesalahankesalahan siswa sesuai dengan indikator kemampuan pemahaman matematis yang diteliti dengan memilah-milah data ke dalam jenis-jenis kesalahan jawaban.

\section{b. Tahap Selective Coding}

Pada tahap ini, peneliti melakukan pendalaman terhadap kategori-kategori yang muncul pada tahap open coding, kemudian dilakukan pengkajian terhadap kategori tersebut yang kemudian akan menjadi kategori inti. Pada tahap ini, lembar jawaban siswa yang dianalisis berdasarkan jenis kesalahan sesuai kategori kesalahan yang dilakukan siswa. Peneliti memilih salah satu dari kategori yang ada dan sebagai inti yang sedang diteliti. Seluruh kategori lainnya dihubungkan pada inti penelitian ini, seperti faktor-faktor penyebab (faktor-faktor yang mempengaruhi kesalahan siswa dalam menjawab dan kondisi yang mempengaruhi.

\section{c. Tahap Theoretical Coding}

Pada tahap ini, peneliti menyusun teori atau konjektur berdasarkan pengkajian kategori-kategori yang ditemukan pada tahap grounded theory. Peneliti menyusun kesalahankesalahan siswa yang muncul berdasarkan indikator kemampuan pemahaman matematis kemudian mengaitkan dengan langkah-langkah yang terdapat pada pembelajaran kontekstual. Sehingga diperoleh kesulitan-kesulitan belajar dalam menyelesaikan soal-soal kemampuan pemahaman matematis siswa dalam pembelajaran. Rangkuman hasil kesalahan jawaban siswa pada soal secara keseluruhan disajikan pada tabel berikut ini. 
Tabel 1 Rangkuman Hasil Kesalahan Jawaban Siswa Kemampuan Pemahaman Matematis Setiap Soal (\%)

\begin{tabular}{|c|c|c|}
\hline \multirow[t]{2}{*}{ Indikator } & \multirow{2}{*}{$\begin{array}{l}\text { No. } \\
\text { Soal }\end{array}$} & \multirow{2}{*}{$\begin{array}{c}\text { Pembelajaran } \\
\text { Kontekstual }\end{array}$} \\
\hline & & \\
\hline \multirow{6}{*}{$\begin{array}{l}\text { Mendefinisikan } \\
\text { konsep secara } \\
\text { verbal dan tulisan }\end{array}$} & 1 & 15,63 \\
\hline & 2 & 21,88 \\
\hline & 3 & 62,50 \\
\hline & 4 & 21,88 \\
\hline & 5 & 15,63 \\
\hline & 6 & 43,75 \\
\hline & ta-rata & 30,21 \\
\hline \multirow{7}{*}{$\begin{array}{l}\text { Menggunakan } \\
\text { model, diagram dan } \\
\text { simbol-simbol untuk } \\
\text { merepresentasikan } \\
\text { suatu konsep, }\end{array}$} & 1 & 21,875 \\
\hline & 2 & 18,75 \\
\hline & 3 & 78,13 \\
\hline & 4 & 15,63 \\
\hline & 5 & 12,50 \\
\hline & 6 & 65,63 \\
\hline & ta-rata & 35,42 \\
\hline \multirow{7}{*}{$\begin{array}{l}\text { Mengenal berbagai } \\
\text { makna dan } \\
\text { interpretasi konsep }\end{array}$} & 1 & 15,63 \\
\hline & 2 & 12,50 \\
\hline & 3 & 59,38 \\
\hline & 4 & 9,38 \\
\hline & 5 & 12,50 \\
\hline & 6 & 53,13 \\
\hline & ta-rata & 27,09 \\
\hline \multirow{7}{*}{$\begin{array}{l}\text { Mengidentifikasi } \\
\text { sifat-sifat konsep } \\
\text { dan mengenal } \\
\text { syarat yang } \\
\text { menentukan suatu } \\
\text { konsep }\end{array}$} & 1 & 12,50 \\
\hline & 2 & 71,88 \\
\hline & 3 & 75,00 \\
\hline & 4 & 34,38 \\
\hline & 5 & 43,75 \\
\hline & 6 & 68,75 \\
\hline & ta-rata & 53,05 \\
\hline
\end{tabular}

Berdasarkan hasil analisis kesalahan jawaban siswa, diperolah bahwa siswa masih banyak kesalahan dalam indikator mengidentifikasi sifat-sifat konsep dan mengenal syarat yang menentukan suatu konsep sebanyak 53,05\%. Kesalahan siswa yang dilakukan siswa paling sedikit terdapat pada indikator mengenal berbagai makna dan interpretasi konsep sebesar 27,09\%. Berarti siswa sudah mampu mengubah soal cerita yang atau soal yang berbentuk kontekstual ke dalam bentuk atau model matematika setelah diberikan pembelajaran kontekstual. 
Tabel 2 Rangkuman Rata-rata

Kesalahan Siswa secara Keseluruhan (\%)

Indikator

Pembelajaran

\begin{tabular}{lc}
\cline { 2 - 2 } & Kontekstual \\
\hline $\begin{array}{l}\text { Mendefinisikan konsep secara } \\
\text { verbal dan tulisan }\end{array}$ & 30,21 \\
\hline $\begin{array}{l}\text { Menggunakan model, diagram } \\
\text { dan simbol-simbol untuk } \\
\text { merepresentasikan suatu konsep }\end{array}$ & 35,42 \\
\hline $\begin{array}{l}\text { Mengenal berbagai makna dan } \\
\text { interpretasi konsep }\end{array}$ & 27,09 \\
\hline $\begin{array}{l}\text { Mengidentifikasi sifat-sifat } \\
\text { konsep dan mengenal syarat yang } \\
\text { menentukan suatu konsep }\end{array}$ & 53,05 \\
\hline Jumlah & \\
\hline
\end{tabular}

Berdasarkan tabel di atas, menunjukkan bahwa siswa masih kurang mampu dalam menjawab soal kemampuan pemahaman matematis dalam mengidentifikasi konsep dan syarat untuk menentukan konsep sebesar 53,05\%. Hal tersebut kemungkinan siswa masih kurang aktif dalam pembelajaran kontekstual pada tahap menerapkan konsep keterkaitan (relating). Namun pada proses pembelajaran, siswa belajar aktif bekerja sama dan saling bertanya sesama rekan.

Pada akhir pembelajaran matematika, siswa diminta memberikan pendapatnya dengan cara di wawancara. Berdasarkan tanggapan yang diberikan dapat disimpulkan bahwa siswa memberikan apresiasi yang positif terhadap pelaksanaan pembelajaran matematika Kontekstual. Siswa merasa senang dan mudah dalam belajar matematika, bahkan mereka mengatakan mampu menyelesaikan soal kemampuan pemahaman matematis.

\section{KESIMPULAN}

Berdasarkan hasil penelitian, Dalam proses pembelajaran pada tahap menerapkan konsep masih kurang, sehingga kesalahan yang banyak dilakukan siswa pada mengidentifikasi konsep dan mengenal syarat untuk menentukan konsep. Hasil analsis diperoleh bahwa siswa masih melakukan kesalahan pada indikator mengidentifikasi konsep dan mengenal syarat untuk menentukan konsep sebanyak 53,05\%. 


\section{REFERENSI}

(2016). Kamus Besar Bahasa Indonesia. [Online]. Tersedia di: http://bahasa.kemdiknas.go.id/kbbi/index.php. Diakses 22 November 2016

Badan Standardisasi Nasional Pendidikan (2006). Pedoman Penyusunan Kurikulum Tingkat Satuan Pendidikan. Jakarta: Depdiknas.

Bardu, O.C. \& Beal, C.R. (2010). Cooperatif Learning, Mempraktikkan Cooperatif Learning Di Ruang-Ruang Kelas. Jakarta: PT. Gramedia.

Cahyo. (2013). Panduan Aplikasi Teori-Teori Belajar Mengajar. Jogjakarta :DIVA Press.

Mahmuda, A. (2011). Diagnonis Kesalahan Siswa Menyelesaikan Soal Bentuk Pangkat, Akar, dan Logaritma Di Kelas X MAN 3 Malang. Skripsi tidak Diterbitkan. Malang: Universitas Negari Malang.

Malau, L. (1996). Analisis Kesalahan Jawaban Siswa Kelas I SMU Kampus Nommense Pematang Siantar dalam Menyelesaikan Soal-Soal Terapan Siswa Persamaan Linier 2 Variabel. Tesis tidak Diterbitkan. Malang: IKIP Malang.

NCTM. (2000). Curriculum and Evaluation Standard for School Mathematics. Reston. VA: NCTM.

OECD. (2013). PISA 2012 Assessment and analytical framework: mathematics, reading, science, problem solving and financial literacy. OECD Publishing.

Suherman, E. (2008). Strategi Pembelajaran Matematika. [Hands-out Perkuliahan: Belajar dan Pembelajaran Matematika]. Bandung: Tidak diterbitkan.

Suherman, E. (2001). Strategi Pembelajaran Matematika Kontemporer. Bandung: Kerjasama JICA dengan FMIPA UPI.

Suyadi. (2013). Strategi Pembelajaran Pendidikan Karakter. Bandung : PT Remaja Rosdakarya. 